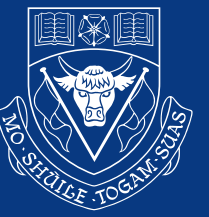

UNIVERSITY OF CALGARY

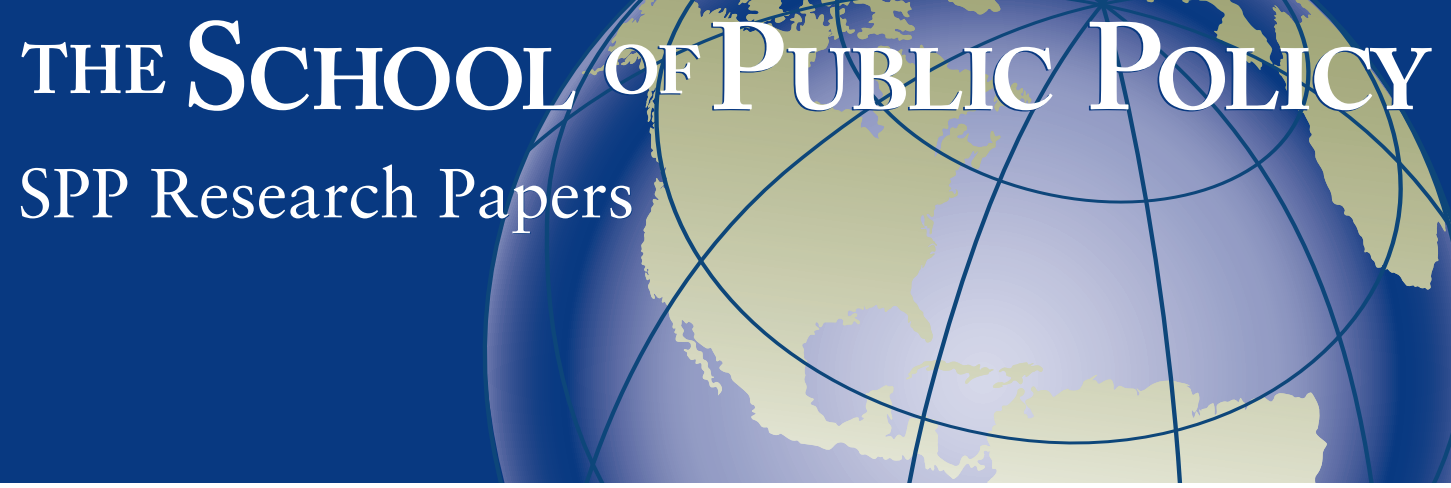

Volume 3・Issue 10 • December 2010

\title{
Fixing the Fiscal Imbalance Turning GST revenues over to the provinces in exchange for lower transfers
}

\section{Kenneth J. Boessenkool}

The School of Public Policy, University of Calgary ${ }^{1}$

\section{ABSTRACT}

The central argument of this paper is that Canada should better align provincial own-source revenues with provincial expenditures by turning over the GST to the provinces while simultaneously reducing federal transfers. The paper begins by broadly outlining of Canada's present fiscal arrangements and explains why a reduction of cash transfers and realignment of federal and provincial tax rates - in short, a transfer of tax points - would benefit the federation. It reviews past tax point transfers and then addresses the question of why transferring GST revenues is superior to other alternatives using the principles of tax assignment as the guide. It lays out two comprehensive proposals for transferring GST revenues, with the key difference being the way in which the GST transfer is equalized across provinces. It shows the impact on Ottawa and the provinces of these two proposals for the 2009-2010 fiscal year. It highlights the benefits of these changes from a federal, provincial and taxpayer perspective with a special focus on one of Canada's major expenditure challenges what to do about public health spending.

I thank Richard Bird and Michael Smart from the University of Toronto for assistance and comments on an earlier draft of this paper. Ron Kneebone, Jack Mintz and other anonymous reviewers contributed to making my arguments stronger. I retain full responsibility for any errors or weakness that remains. 


\section{INTRODUCTION}

Recent moves to harmonize the federal GST with provincial sales taxes in British Columbia and Ontario may have finally created the conditions to make the next big move to address the fiscal imbalance in Canada.

Essentially, the fiscal imbalance is simple: at current tax rates, the federal government has more revenue than they need for their expenditures, and the provinces (as a group) have less revenue at their current tax rates than they need for their expenditures.

Canada has closed the resulting gap by converting large amounts of federal revenues to provincial revenues through intergovernmental transfers. The result has been considerable peace on this issue since the federal government made much of the fact that it restored fiscal balance in Budget 2007. If fiscal balance means that provinces and the federal government have revenues - from whatever source - at least broadly consistent with their spending responsibilities, then this claim is arguably justified. To quote just one source on the size of the fiscal imbalance, Quebec's Commission on Fiscal Imbalance claimed in 2002 that: "For Canada as a whole, the need for resources that the Commission has quantified implies that the provinces should receive an adjustment to their financial resources of at least $\$ 8$ billion in the short term." ${ }^{2}$ Given that federal transfers for social programs (not including the federal equalization program) increased from just over $\$ 19$ billion in 2002-2003 to nearly \$35 billion in 2009-2010, this condition has clearly been satisfied.

Yet a different perspective on fiscal balance raises the question of whether this is indeed a cure or merely a treatment of symptoms. This perspective is summarized in 2005 by Ken McKenzie in a C.D. Howe Institute paper on fiscal federalism: "Growing federal transfers set the stage for perpetual fiscal imbalances and continuing political instability. A politically and economically sustainable alternative is to increase provincial own source revenue."

The recent move to harmonize the GST across Canada provides an opportunity for a potential solution. The federal government could turn GST revenues over to the provinces, while at the same time substantially reduce federal transfers. Doing so would make Canada's fiscal structure more rational in terms of who pays for what. If the remaining provinces seize the occasion to also harmonize their consumption tax base, it would facilitate growth at the same time.

The central argument of this paper is that what is needed is a reform that improves accountability and helps to eliminate these transfer games. It proposes options on how this could be achieved. First, the paper describes the broad outlines of Canada's present fiscal arrangements and explains why a reduction of cash transfers and realignment of federal and provincial tax rates would benefit the federation - in short, a transfer of tax points. It reviews past tax point transfers and then addresses the question of why transferring GST revenues is superior to other alternatives using the principles of tax assignment as the guide. It lays out two comprehensive proposals for transferring GST revenues, with the key difference being the way in which the GST transfer is equalized across provinces. It shows the impact on Ottawa and the provinces of these two proposals for the 2009-2010 fiscal year. It highlights the benefits of these changes from a federal, provincial and taxpayer perspective with a special focus on one of Canada's major expenditure challenges - what to do about public health spending.

2 Commission on Fiscal Imbalance, 133.

3 Ken McKenzie, Reflections on the Political Economy of Fiscal Federalism in Canada (Toronto: C.D. Howe Institute Working Paper, September 20050, p. i. 


\section{TRANSFER GAMES}

Smart and Bird succinctly lay out what they label "transfer games" which is worth quoting at length, ${ }^{4}$

Under our current system, the fiscal gap between Ottawa and the provinces is

large and persistent. Currently the federal government raises some $\$ 50$ billion $^{5}$ in taxes each year that it simply transfers to the provinces to spend on health, education and social services.

The result is what can only be described as Canada's 'co-dependent' constitutional relations: with our current fiscal arrangements, Ottawa raises the money and the provinces spend it. The result of this fiscal churning is that no government has clear responsibility for delivering key programs and both sides readily blame the other when something goes wrong.

The dynamics of the blame game are evident in the history of the Canadian Health and Social Transfer (CHST), where the level of federal cash allocated to the program has been increased in virtually every federal budget since the initial cuts of 1995. Cash transfers for social programs that were under $\$ 20$ billion in 2002-2003 are scheduled to rise to nearly $\$ 40$ billion by 2013-2014. In the 10 years before 2002-2003, these transfers fluctuated from a high of almost \$19 billion in 1993-1994 to a low of \$12.5 billion in 1997-1998 and 1998-1999, only to rise to $\$ 20$ billion in 2002-2003. In short, the result is a federal government that is unable to commit credibly to a stable transfer system with clear and consistent incentives. Provincial governments have little incentive today to set their own fiscal houses in order, since spending restraint weakens the case for future increases in federal transfers.

Of course, federal bailouts of provincial spending inevitably come at the expense of federal taxpayers - who are provincial taxpayers and voters as well. Shouldn't this eliminate incentives for the provinces to attempt to finance provincial spending with federal revenues? Not in the current environment, given the extent to which federal transfers are disproportionately borne by more wealthy taxpayers who reside in greater numbers in a few provinces (historically mostly Ontario, Alberta and B.C., though more recently Saskatchewan and Newfoundland), and the evidence that each province may obtain its own deal from Ottawa through bilateral negotiation. In these circumstances, federal tax revenues are in effect a common pool of resources that is available to whoever is the first to exploit them. Like all poorly managed common property resources, the result is an inevitable tendency to exploitation. We end up with a race among provincial governments to exploit taxpayers who reside in other provinces through federal transfer negotiations.

4 Michael Smart and Richard Bird, "The GST Cut and Fiscal Imbalance" (Toronto, International Tax Program, Rotman School of Management, 2006). The indented section is, with a couple small updates and edits, a copy of a similarly titled section in the Smart and Bird paper. I again thank Smart and Bird for their cooperation and assistance with earlier drafts of this paper.

5 The difference between this number and the $\$ 32$ billion above is principally equalization. 
The common-pool problem cannot, however, explain the tendency for even the have provinces to push for greater per capita federal transfers, since the only reasonable expectation is that equal per capita transfers will be financed disproportionately by taxpayers in a few provinces. Current transfer arrangements, then, create a further problem of 'fiscal illusion' on the part of voters and their elected leaders - as Winer pointed out decades ago. When the premiers call for more federal transfers, they pretend this could be done without increasing the federal tax and debt burden on their own citizens. Naturally, the premiers would like to spend more without raising taxes themselves. It is only the current system of murky shared responsibility that makes this seem like more than a pipe dream.

The critical point is that, in the absence of clean lines of accountability in tax and spending decisions, the current policy stance of both federal and provincial governments is self-reinforcing: Canada is stuck in a sort of low-level intergovernmental fiscal equilibrium. One of the most important long-term issue facing Canadian taxpayers is whether further increases in public health care spending per capita are warranted, or whether more fundamental reforms to the health system are desired. But provincial governments have little incentive to frame the question this way for voters when the option to argue for transfer increases is available. The federal government also faces an implicit incentive to accommodate provincial demands, as long as voters apparently reward federal governments that do little more than write larger and larger cheques. What is needed is a reform that improves accountability and helps to eliminate these transfer games.

A properly designed tax point transfer would put an end to the continued renegotiation of federal transfers and the resulting fiscal illusion for voters. If provinces wished to spend more on health care they would have to increase taxes directly, and face the wrath of voters on Election Day if their decisions were the wrong ones. The change might increase voter satisfaction with the federal government as well. No longer would federal tax payments seem to disappear into thin air. Both levels of government would have much stronger incentives to act responsibly. That all sounds good, but the question is: How can it be done without wrecking Canada's sometimes precarious regional and political equilibrium?

Some commentators ${ }^{6}$ have suggested that the solution to fiscal imbalance is a very simple one: with the reductions in the federal GST, the provinces can simply increase their own sales taxes unilaterally if they choose, in effect transferring tax powers without further reforms or negotiations between levels of government. Indeed, the 2007 federal budget defended GST reductions in precisely these terms. ${ }^{7}$ And now that most provinces with the largest portion of Canada's population and economy will soon have harmonized sales taxes, this potential solution has become much easier.

6 For example, John Ibbitson, The fiscal imbalance bogeyman, in The Globe and Mail, (March 3, 2006), A4.

7 The Budget Plan 2007, Aspire to a Stronger, Safer, Better Canada, March 19, 2007, 109. http://www.budget.gc.ca/2007/pdf/bp2007e.pdf. 
But this would be problematic in those provinces that have not yet harmonized. In those provinces (Saskatchewan, Manitoba and Prince Edward Island) two wrongs don't make a right: ${ }^{8}$ the sales taxes currently charged in these provinces are extremely badly designed, and they should not be substituted for the relatively efficient though unpopular federal GST. These three provinces impose retail sales taxes - though they certainly do not apply only to retail sales to final consumers - with bases very different from the federal GST. This difference in bases creates a problem for shifting tax effort to the provinces, but it creates an opportunity for reform as well - it is yet another argument for these provinces to harmonize with the federal GST. Lesser issues are that Quebec's sales tax, the QST, while a value added tax (VAT) like the GST, is not levied on exactly the same base, and, more importantly, that under the present HST imposed in Nova Scotia, New Brunswick and Newfoundland and Labrador, the provinces are unable to decide on their own tax rates.

Having provinces take up vacated GST room is an important but simple solution, but it only deals with the revenue side of the equation - it doesn't address the need to also reduce federal transfers to provinces. A much more radical solution would have the federal government transfer all GST revenues to the provinces at the same time as it substantially reduces federal transfers - in short a GST tax point transfer coupled with reductions in federal transfers to provinces.

\section{A BRIEF REVIEW OF PAST TAX POINT TRANSFERS}

Prior to World War II, Canada and the provinces each levied a bewildering array of taxes that was commonly referred to as a 'tax jungle.' In 1937, the federal government created the Rowell-Sirois Commission to examine these fiscal arrangements and provide recommendations. In 1940, the Commission recommended that the federal government exclusively occupy personal, corporate and inheritance tax fields and in return assume all provincial debt and pay national adjustment grants to poorer provinces.

While the recommendations of the commission were rejected, a federal-provincial conference in 1941 resulted in the provinces relinquishing their access to personal, corporate and inheritance taxes in recognition of the burdens the federal government faced to fund the war effort - in effect, a large tax point transfer from the provinces to the federal government. In return, the provinces received grants from Ottawa.

In the years following WWII, Ottawa established various shared cost programs with the provinces as provincial expenditures grew with the expansion of the welfare state. At the same time, provinces increased pressure on Ottawa to give them back some of the tax room they had transferred to the federal government to fund the war effort. 
This culminated in the creation of the Established Program Financing (EPF) in 1977. EPF was a combination cash and tax point transfer to fund hospital insurance, medicare and post-secondary education. EPF was to fund half of these provincial expenditures via a cash transfer plus 13.5 points of personal income tax and one point of corporate income tax. The federal government lowered its take in return for provinces increasing their take of these taxes a tax point transfer. In effect, EPF resulted in the federal government providing a cash contribution to provinces that covered one quarter of the costs of these programs, with the tax point transfer covering another quarter.

These tax points were worth more in richer provinces than in poorer provinces. The equalization program captured a portion of the differences in the value of these tax points. In addition, the federal government reduced the cash portion paid out to wealthier provinces so that the tax points were fully equalized. This latter adjustment became known as 'associated equalization' to distinguish it from actual payments made in the equalization program.

This associated equalization has become the source of much controversy. ${ }^{10}$ On the one hand, it has been referred to as back door equalization that should be eliminated. ${ }^{I 1}$ On the other hand, the lack of transparency of associated equalization has led to calls that the federal government should establish a Tax Point Adjustment program to explicitly pay this associated equalization as a distinct federal expenditure program. ${ }^{12}$

Recent federal budgets start to move in the direction of eliminating associated equalization. This would remove associated equalization from the Canada Social Transfer (CST) by turning it into an equal per capita cash transfer, and commits to moving the Canada Health Transfer (CHT) to equal per capita when the 10-Year Plan to Strengthen Health Care expires in 2014."13

Clearly, a realignment of consumption tax rates would be worth more to the rich provinces than the poor ones. The existing equalization system would deal with that automatically to some extent, ensuring that the additional provincial tax room had the same value to all equalizationreceiving provinces. But that still leaves Alberta and (to some extent) Ontario and B.C. getting more. To be absolutely clear: the do-nothing reform proposed by some, in which the federal government decreases the GST unilaterally and leaves provinces to raise their tax rates if they choose, would result in an implicit transfer of resources from have-not to have provinces that a majority of provinces would likely oppose.

9 This historical summary of transfers draws heavily from the Advisory Panel on Fiscal Imbalance, Reconciling the Irreconcilable: Addressing Canada's Fiscal Imbalance, (Council of the Federation, March 31, 2006), 21-25.

10 Ken Boessenkool, The Illusion of Equality: Provincial Distribution of the Canada Health and Social Transfer (C.D. Howe, January 1996).

11 Expert Panel on Equalization and Territorial formula Financing, Achieving a National Purpose: Putting Equalization Back on Track (Department of Finance, Ottawa, May 2006), 47. See also Tom Courchene, Redistributing Money and Power: A Guide to the Canada Health and Social Transfer (Toronto: C.D. Howe, January 1995).

12 Advisory Panel on Fiscal Imbalance, Reconciling the Irreconcilable: Addressing Canada's Fiscal Imbalance, (Council of the Federation, March 31, 2006), 71-73. Note that the Government of Ontario explicitly rejected the creation of this Tax Point Adjustment Program. Government of Ontario News Release, Statement by Premier Dalton McGuinty on Report of the Council of the Federation Panel (April 11, 2006). http://news.ontario.ca/opo/en/2006/04/statement-bypremier-dalton-mcguinty-on-report-of-the-council-of-the-federation-panel.html

13 This was principally done in The Budget Plan 2007, Aspire to a Stronger, Safer, Better Canada, (March 19, 2007), Annex , 359-361. http://www.budget.gc.ca/2007/pdf/bp2007e.pdf. 


\section{WHY THE GST?}

The 1997 final report of the Technical Committee on Business Taxation provides a useful set of principles for coordinating taxing authority." ${ }^{14}$ It is worth testing the transfer of GST revenues in light of five principles proposed by the Technical Committee proposes. This will also allow to address reasons why transferring the GST is superior to transferring additional personal income tax room. ${ }^{15}$ Those principles include the following:

\section{Encouraging the free flow of goods, services, capital and labour in the economic union}

Under this principle, "all levels of government would refrain from levying taxes that would impair the flow of goods and services, capital and labour across provincial boundaries or that would discriminate against businesses owned by residents of other provinces."16

A possible objection against transferring GST revenues to provinces is that the GST is an important part of the federal government's tool kit for fiscal stabilization. The GST can be used both as an automatic as well as a discretionary stabilizer. In terms of automatic stabilization, so long as all provinces continue to levy some level of GST, it will continue to function as a national tool for economic stabilization. In addition, as noted below, the GST is less volatile than other revenue sources. Whether this budget (as opposed to economic) stabilization is better suited to provincial rather than federal determination is a matter of taste.

The federal government used the GST as a discretionary stabilizer in the recent downturn. ${ }^{17}$ Clearly, if Ottawa transferred GST revenues to the provinces, they would cease to have this discretionary tool in their toolkit. Yet there is no reason why provinces could not do this in a coordinated fashion. Even if not coordinated, the GST in provincial hands could potentially be a powerful tool to address differences in regional economic swings. ${ }^{18}$

Transferring GST revenues to the provinces may enhance our national economic union by providing a strong incentive for the remaining provinces to move to a system of provincial VATs. This would clearly increase provincial (and hence Canada's) competitiveness. ${ }^{19}$

Finally, transferring the entire GST to provinces, as opposed to a portion of the personal or corporate income tax, would make it much more difficult for the federal government to re-occupy this tax room in the future, as Ottawa has arguably done with the personal income tax points it transferred in $1977^{20}$ - which has arguably resulted in a higher total tax burden than would otherwise be the case.

\footnotetext{
14 Report of the Technical Committee on Business Taxation (Ottawa: Department of Finance, 1997), 11.3-11.4. I borrow liberally from the Committee report in this section. See also Irene Ip and Jack Mintz, Dividing the Spoils: The federal-Provincial Allocation of Taxing Powers (Toronto: C.D. Howe Institute, 1992). Ip and Mintz also recommend a GST transfer to the provinces in this volume, see p. $123 \mathrm{ff}$.

15 As argued, for example in Paul Boothe and Derek Hermanutz, Simply Sharing: An Interprovincial Equalization Scheme for Canada (Toronto: C.D. Howe Institute, July 1999).

16 Technical Committee, 11.3.

17 See Ken Boessenkool, Unleash consumer spending with a temporary GST cut, Toronto Star (November 27, 2008).

18 For a discussion of these issues see Ron Kneebone, National Stabilization Policy and its Implications for Western Canada, (Calgary: Canada West Foundation, 2008).

19 Jack Mintz, Ontario's Bold Move to Create Jobs and Growth, The School of Public Policy Communique, Volume 1, Issue 4, November 2009.

20 See Commission on Fiscal Imbalance, A New Division of Canada's Financial Resources (Government of Quebec, 2002), 142-143, esp. Chart 41.
} 
When compared to a transfer of income taxes, consumption taxes are probably less distortive to trade flows as they are destination-based taxes (with exports exempt and imports taxed). The only impact would be individuals going across the border to buy goods and services, but they have to do this as tourists as mail order and internet order are taxed at destination. From a more macro perspective, income tax differentials would have a much larger impact on labour flows and production decisions, making them potentially more distorting.

\section{Minimizing the fiscal spillover effects of federal and provincial government tax policies}

Under this principle, "there are instances where the tax policies of one government may directly affect the economic well-being of the residents of another jurisdiction. Such interactions, or fiscal spillovers, occur among governments at the same level of jurisdiction (provinces) as well as between federal and provincial governments, and should be minimized." 21

These spillovers can include tax exportation (when taxes in one jurisdiction fall on residents or governments in another jurisdiction), tax base flight (when taxes on a mobile factor cause it to flee) and joint occupancy (when raising taxes in one jurisdiction causes the revenues of that tax source to fall in another).

As a destination-based tax, the GST will have little impact on tax base flight or tax exportation paid by residents. In addition, and unlike income taxes, the GST would not have any impact on capital income. This is particularly relevant for the personal income tax treatment of capital gains and dividends where the relief on the personal side in one province is helping to pay for the corporate tax in another province.

\section{Minimizing the cost of administration and compliance}

Perhaps the most serious criticism of giving provinces control over the GST is that it would result in ten separate administrations with various provinces making changes to the tax base in ways that would result in spillover effects. There is the very serious challenge of "carousel trading' across provincial boundaries that would result from having multiple administrations and bases for the GST. The issue here is that provinces exempt exports and do not allow imports to be deducted from the base. Currently, the federal administration and auditing ensure that these issues are addressed between Canada and its trading partners, but there is no need to do so between provinces with a single administration and tax base.

The solution is that the federal government should continue to administer, collect and audit the GST, even though all revenues would be turned over to the provinces.

First, our constitution clearly assigns responsibility for trade and commerce to the federal government. Even in a world where Ottawa transferred full responsibility for GST administration and collection over to the provinces, it could arguably use its trade and commerce powers to enforce a common base and resolution of these issues as part of these powers. ${ }^{22}$

\footnotetext{
21 Technical Committee on Business Taxation, 11.3-11.4

22 These are the same powers many commentators argue that Ottawa should use to unilaterally eliminate interprovincial trade barriers.
} 
Second, there is a strong precedent for a 'tax on base' approach in Canada. Our current personal income tax works this way. With some exceptions and subject to tax collection agreements, Ottawa determines the base for personal income taxes in Canada and provinces determine the rate. ${ }^{23}$ There is no reason why Ottawa and the provinces could not come to a similar arrangement on the GST - in fact, the recent moves to harmonize the GST have demonstrated that the provinces can do exactly that.

Some may argue that these tax collection agreements only work when tax bases are shared, but the provinces would never accept a federally determined base on a solely provincial revenue source. This objection can be dealt with for these reasons:

- A carrot: The harmonizing provinces have given up control over their sales taxes when they converted to a harmonized sales tax. They simply realized that the economic benefits of harmonizing outweighed the lost autonomy they had with a retail sales tax. This was buttressed by the savings they could realize on collection and administration. This is a reason why the federal government should be willing to continue to bear the costs of collection and administration of the GST even if it will not receive revenues, though they could charge the provinces for this service, since it would be cheaper for virtually all provinces to agree to a single collection agency. ${ }^{24}$ In short, federal administration and collection would save the provinces money.

- A stick: The federal government will, even after it transfers GST revenues and reduces transfers, still have a federal transfer to the provinces. Ottawa could make that transfer partly conditional on the provinces not stepping outside of a federally administered, collected and enforced GST. Indeed, the federal government has a much stronger constitutional argument for making these kinds of conditions, which are related to trade and commerce, than they do for making conditions under the Canada Health Act. Ottawa could threaten to withhold transfers for any province who violates the GST tax collection agreement.

- An example: While the parallels are not complete, this is precisely what Australia does with their GST. ${ }^{25}$ Their national government collects the GST and then distributes the revenues to their state governments. While Canada doesn't have to emulate the way in which Australia distribute their GST revenues, ${ }^{26}$ that country's national government does not receive revenues from their GST, but still oversees its administration, collection and harmonization across Australian states.

- As Bird shows, a system with differentiated provincial rates on a similar base can be administered with no technical or administrative problems.

Provinces - particularly as we enter a period of restraint - have strong incentives to prefer a GST transfer to federal cash transfers. In such environment, they would likely be willing to allow Ottawa to collect and administer the GST if they were given full control over the rate and revenues.

\footnotetext{
23 The exception is Quebec which has its own tax base, administration and collection.

24 Again, Quebec is the current exception here - their harmonized GST is collected and administered provincially.

25 The key difference is that Australia uses their GST revenues to achieve horizontal equity between provinces something we do with our equalization program. What is proposed here is to use GST revenues to achieve (greater) vertical equity.

${ }^{26}$ For a criticism of the Australian approach of incorporating needs into their equalization program see Kenneth J Boessenkool, Clearly Canadian: Improving Equity and Accountability in an Overarching Equalization Program (Toronto: C.D. Howe Institute, 1997), 8-9.
} 


\section{Facilitating autonomy and flexibility for governments}

Under this principle, "each level of government requires access to sources of revenue to fund its activities... adequate revenues sources play an important role in facilitating autonomous and flexible decision-making by governments."27

This ground has been well tilled in the discussion above, though additional points are worth noting over whether a transfer of income tax room would be superior to a transfer of GST revenues.

FIGURE 1: Volatility: Transfers vs. GST vs. Income Taxes

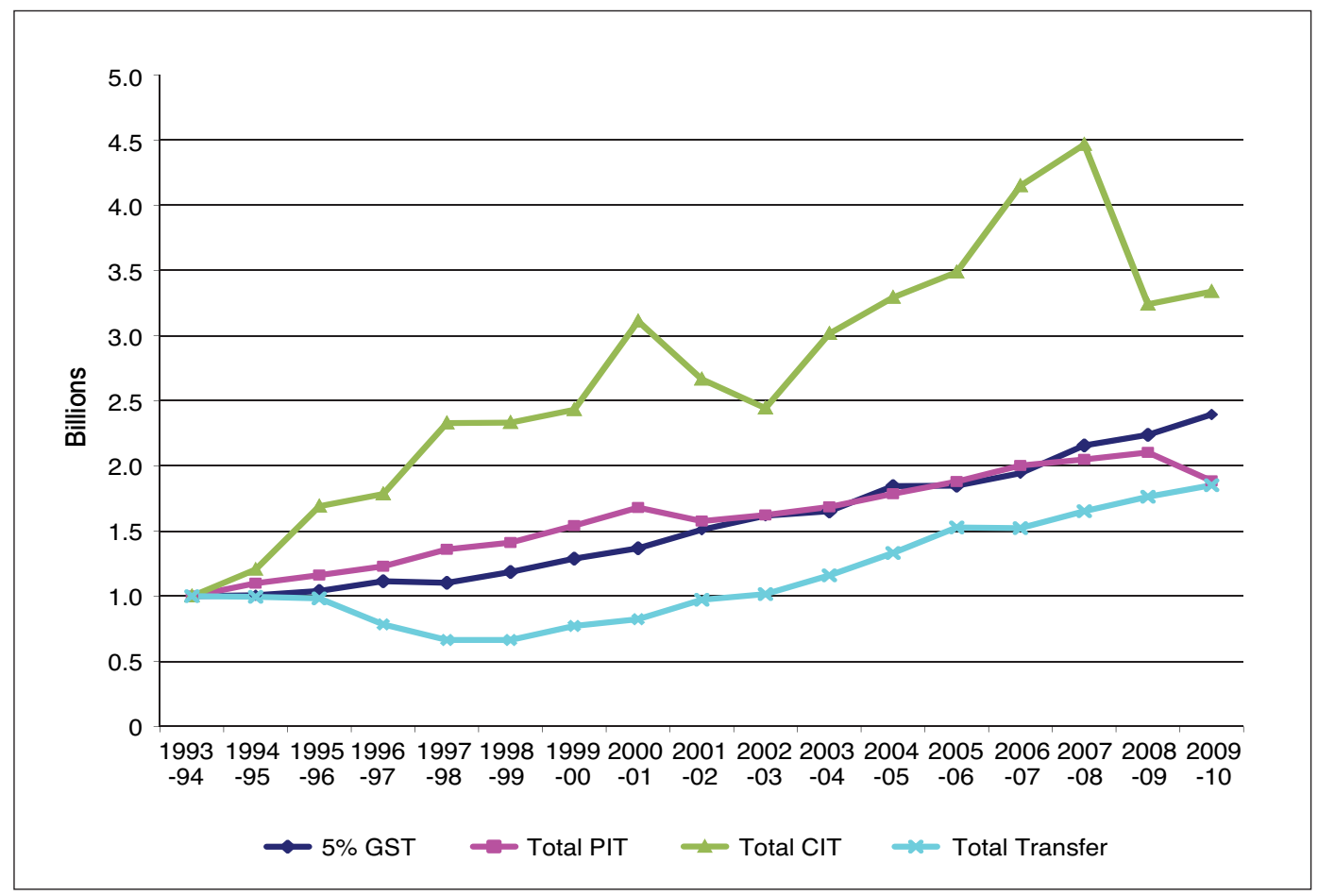

Note: Nominal Federal GST collections based on a constant 5\% rate versus total nominal PIT and CIT revenues and total federal transfers excluding equalization - EPF and CAP to 1995/96, then CHST to 2003/04 then CST and CHT plus supplements to 2009/2010. All nominal data then converted to an index where 1993/94 = 1 .

First, the GST is a much more stable revenue source than income taxes and thus a better match with provincial expenditures on social programs. The GST is less volatile over time compared to income taxes as consumption is less variable than income - whether personal or corporate. Figure 1 shows federal personal and corporate income tax revenues as well as GST collections if the rate had been 5\%, alongside a profile of total federal cash transfers. Given the choice, most provinces would be hard pressed not to prefer the trajectory of GST collections to income taxes or actual transfers to fund health and other social programs. Tying the funding of social programs to GST revenue would provide more stability over time to provincial budgets.

27 Technical Committee on Business Taxation, 11.4 
In addition, the variation of the GST across provinces is less than the variability of income taxes. The fiscal capacity for the GST ranged from around $81 \%$ of the national average for Newfoundland to $132 \%$ for Alberta in 2007 (the latest year for which this data is available). In 2007-2008, the Department of Finance estimates that personal income tax fiscal capacities ranged from 57\% for Prince Edward Island to a high of 142\% for Alberta. The lower variability for the GST means that Ottawa would have to pay less to equalize any transfer of GST points than they would for personal income tax points.

Second, the current federal GST collects less money than is currently transferred to provinces. This means that the entire GST can be given to provinces with a corresponding decrease in federal transfers. This would give provinces exclusive access to this critical tax base. Given that provinces have exclusive responsibilities, they should be matched with tax bases that are exclusively in their jurisdiction. ${ }^{28}$

\section{Improving the accountability of governments}

In the words of the Technical Committee, "requiring that governments fund their programs through taxation, rather than relying on transfers from another level of government, can improve accountability." This is the central argument of this paper.

One area that requires consideration is the GST Credit paid out by Ottawa to low income families through the personal income tax system. While some have argued that the GST credit is just another federal spending program that has little to do with the GST, ${ }^{29}$ the GST credit would not exist today without the GST. If provinces took over the GST, they would almost certainly want to take over the GST credit as well. And from an economic perspective, the GST can be made more progressive through a GST Credit type of mechanism, which is more efficient and preferable than exempting certain goods - such as food, clothing and some services - from the GST.

At least three options are available to address the GST Credit:

- It could be rolled into and integrated into the existing Child Tax Credit System by the federal government. This would detach the GST credit from the GST, which may cause provinces some political challenges on the progressivity front.

- It could be simply maintained by the federal government as it stands today. The federal government could continue to provide a GST credit to all Canadians. Under this option, Ottawa could even vary the size of the credit by province to reflect differential provincial GST rates.

- Provinces could take it over (whether administered federally or provincially) as a provincial program delivered through their provincial income tax system. Doing so would be fairly simple, as the federal government collects provincial taxes based on a federally determined base for all provinces except Quebec.

Whichever option is chosen, Ottawa and the provinces could net any cost against the remaining federal transfer to ensure fiscal neutrality.

28 This is an in practice rather than an in theory argument, as clearly the federal government would retain the ability to introduce a new broad based sales tax. However, it is probably safe to assume that until the memory of the introduction of the GST becomes very faint, the probability of this happening is in practice very low.

29 Bill Robson first made this case in 1997 and delights in repeating it often in his frequent analysis of federal budgets. See William B.P. Robson, Ottawa's Incredible Disappearing Act: Canadians pay billions more than in tax than the budget shows and the gap is growing (Toronto: C.D. Howe Institute March 1997) as well as his annual pre and post federal budget publications found at www.cdhowe.org. 


\section{MAKING IT WORK: TRANSFERRING GST REVENUES TO PROVINCES}

The federal government could transfer the GST to the provinces in at least two ways. In the first approach, the federal government equalizes GST revenues through a transfer to achieve the national average. This is consistent with the approach of the current government, which is gradually eliminating the associated equalization in existing transfers. The second approach equalizes GST revenues both up and down - by including an additional associated equalization amount for the new transfer that is applied against the residual Canada Social Transfer. This is consistent with how tax points were transferred in 1977 under EPF.

\section{OPTION 1: National Average Equalized Transfer}

From Ottawa's perspective, Option 1 would work as follows if implemented in fiscal year 2009-2010 (see Table 1):

- It transfers a 5\% GST to the provinces, resulting in a reduction in revenues of just under $\$ 26$ billion (see Box 1 for details on methodology for the results in Table 1).

- It eliminates the Canada Health Transfer and Canada Social Transfer to provinces, resulting in a reduction in expenditures of just under $\$ 35$ billion.

- It creates a new Canada Social Transfer worth \$9 billion in 2009-2010, or \$268 per person. It would adjust this Canada Social Transfer by the existing adjustments to the CHT for associated equalization. These associated equalization adjustments take $\$ 700$ million out of Alberta and distributes this money to the other nine provinces. Remember that this is the current associated equalization in the HST; it is not something new to this proposal.

- The GST transfer is equalized to the national average so that the combination of the GST transfer and the additional equalization give each province at least $\$ 767$ per capita. A national average equalization program would cost \$544 million.

- The total impact on Ottawa of these changes would be an additional cost of \$568 million.

From a provincial perspective, all provinces would come out ahead in 2009-2010 from these arrangements - though all provinces except Alberta would see increases of up to 2\% above their current transfer arrangements. Alberta is a big winner, while B.C. and Saskatchewan would be smaller winners because their GST transfer is not equalized down to the national average, as per option 2. In other words, these provinces - and Ontario - get to keep the amount by which their GST collections exceed the national average.

\section{OPTION 2: Fully Equalized National Average GST Equalization}

From Ottawa's perspective, Option 2 would be exactly as Option 1 with the following difference (fiscal year 2009-2010 - see Table 1):

- It would create additional associated equalization in a new Canada Social Transfer with the effect that British Columbia, Alberta and Ontario would have their new Canada Social Transfer adjusted downward by the amount by which their GST per capita exceeds the national average. This new 'associated equalization' requires a reduction of B.C.'s transfer by $\$ 178$ million, of Alberta's transfer by $\$ 425$ million and Ontario's transfer by $\$ 122$ million. Thus the GST tax points would be fully equalized.

- The total impact on Ottawa of these changes would be an additional cost of \$43 million. 
From a provincial perspective, all provinces would have come out ahead in the 2007-2008 fiscal year from these arrangements - though Ontario, Saskatchewan, Alberta and B.C. would see a smaller benefit than for Option 1. This is because the new associated equalization effectively pulls their GST transfer down to the national average. This is done by deducting their payments under the residual Canada Social Transfer.

\section{TABLE 1: Impact of Option 1 and Option 2 on the Federal and Provincial Budgets}

\section{Box 1: Methodology}

Most of the numbers in Table 1 come from combing through the federal Budget Plan for the past 15 or so years. However, no current data exists to calculate a base for equalizing GST revenues across provinces. Three options were attempted. First, the existing base for sales tax in the current equalization formula was tried. The trouble with this is that the base is a combination of provincial HSTs and PSTs, yielding inconsistent results for a GST base. Second, data on GST collected by provinces was examined. This would be the best option, but this data base only goes up to 2006. Finally, personal expenditures on goods and services by province - for which there are data up to 2008 - was examined as a possible proxy. For those years in which there are data for the latter two series (1993-2006) the two series have a correlation of between 99.23 and 99.84 percent over time for each province, and a correlation across provinces in each year of between 99.85 and 99.97. Data for personal expenditures in 2009 were forecast based the TD Bank's provincial forecast for retail sales published in their Provincial Economic Forecast on November 3, 2009. Remaining data came from Statistics Canada or was provided by the Department of Finance.

\begin{tabular}{|l|r|r|}
\hline CANADA & $\mathbf{2 0 0 8 - 0 9}$ & $\mathbf{2 0 0 9 - 1 0}$ \\
\hline 2009 Budget & 22,555 & \\
Canada Health Transfer (CHT) & 10,537 & 10,908 \\
Canada Social Transfer (CST) Per Capita & 33,092 & 34,761 \\
Total & & \\
\hline OPTION 1: Equalized to National Average & & 25,785 \\
Transfer 5\% GST to Provinces & & $-34,761$ \\
Eliminate CHT and CST & & 9,000 \\
New Social Transfer (Note 1) & & 544 \\
National Average Equalization & & 568 \\
Change From Status Quo & & \\
\hline OPTION 2: Fully Equalized National Average Equalization & & 25,785 \\
Transfer 5\% GST to Provinces & & $-34,761$ \\
Eliminate CHT and CST & & 8,475 \\
New Social Transfer (Note 2) & & 544 \\
National Average GST Equalization & & 43 \\
Change From Status Quo & & \\
\hline
\end{tabular}

1 \$268 per capita Transfer adjusted for associated equalization that is currently part of the CHT.

$2 \$ 268$ per capita adjusted for associated equalization that is currently part of the CHT plus new associated equalization from equalizing the GST to the national average. 


\begin{tabular}{|c|c|c|c|c|c|c|c|c|c|c|}
\hline & \multicolumn{2}{|c|}{$\begin{array}{l}\text { NEWFOUNDLAND } \\
\text { AND LABRADOR }\end{array}$} & \multicolumn{2}{|c|}{$\begin{array}{l}\text { PRINCE EDWARD } \\
\text { ISLAND }\end{array}$} & \multicolumn{2}{|c|}{ NOVA SCOTIA } & \multicolumn{2}{|c|}{$\begin{array}{c}\text { NEW } \\
\text { BRUNSWICK }\end{array}$} & \multicolumn{2}{|c|}{ QUEBEC } \\
\hline & $\begin{array}{l}2008 \\
-09\end{array}$ & $\begin{array}{c}2009 \\
-10\end{array}$ & $\begin{array}{l}2008 \\
-09\end{array}$ & $\begin{array}{c}2009 \\
-10\end{array}$ & $\begin{array}{l}2008 \\
-09\end{array}$ & $\begin{array}{l}2009 \\
-10\end{array}$ & $\begin{array}{l}2008 \\
-09\end{array}$ & $\begin{array}{c}2009 \\
-10\end{array}$ & $\begin{array}{c}2008 \\
-09\end{array}$ & $\begin{array}{c}2009 \\
-10\end{array}$ \\
\hline 2009 Budget & & & & & & & & & & \\
\hline Canada Health Transfer & 362 & 372 & 100 & 103 & 669 & 690 & 533 & 550 & 5,520 & 5,716 \\
\hline Canada Social Transfer & 161 & 164 & 44 & 45 & 297 & 303 & 237 & 242 & 2,459 & 2,526 \\
\hline Total & 523 & 536 & 144 & 148 & 966 & 993 & 770 & 792 & 7,979 & 8,242 \\
\hline \multicolumn{11}{|l|}{$\begin{array}{l}\text { OPTION 1: Equalized } \\
\text { to National Average }\end{array}$} \\
\hline Collections From 5\% GST & & 367 & & 100 & & 706 & & 530 & & 5,585 \\
\hline Eliminate CHT and CST & & -536 & & -148 & & -993 & & -792 & & $-8,242$ \\
\hline New Social Transfer & & 146 & & 41 & & 274 & & 218 & & 2,246 \\
\hline National Average GST Equalization & & 23 & & 8 & & 13 & & 44 & & 418 \\
\hline Change From Status Quo & & 0 & & 0 & & 1 & & 1 & & 6 \\
\hline \multicolumn{11}{|l|}{$\begin{array}{l}\text { OPTION 2: Fully Equalized } \\
\text { National Average } \\
\text { Equalization }\end{array}$} \\
\hline Collections From 5\% GST & & 367 & & 100 & & 706 & & 530 & & 5,585 \\
\hline Eliminate CHT and CST & & -536 & & -148 & & -993 & & -792 & & $-8,242$ \\
\hline New Social Transfer & & 146 & & 41 & & 274 & & 218 & & 2,246 \\
\hline National Average GST Equalization & & 23 & & 8 & & 13 & & 44 & & 418 \\
\hline Change From Status Quo & & 0 & & 0 & & 1 & & 1 & & 6 \\
\hline
\end{tabular}

\begin{tabular}{|c|c|c|c|c|c|c|c|c|c|c|}
\hline & \multicolumn{2}{|c|}{ ONTARIO } & \multicolumn{2}{|c|}{ MANITOBA } & \multicolumn{2}{|c|}{ SASKATCHEWAN } & \multicolumn{2}{|c|}{ ALBERTA } & \multicolumn{2}{|c|}{$\begin{array}{c}\text { BRITISH } \\
\text { COLUMBIA }\end{array}$} \\
\hline & $\begin{array}{c}2008 \\
-09\end{array}$ & $\begin{array}{c}2009 \\
-10\end{array}$ & $\begin{array}{c}2008 \\
-09\end{array}$ & $\begin{array}{c}2009 \\
-10\end{array}$ & $\begin{array}{c}2008 \\
-09\end{array}$ & $\begin{array}{c}2009 \\
-10\end{array}$ & $\begin{array}{c}2008 \\
-09\end{array}$ & $\begin{array}{c}2009 \\
-10\end{array}$ & $\begin{array}{c}2008 \\
-09\end{array}$ & $\begin{array}{c}2009 \\
-10\end{array}$ \\
\hline 2009 Budget & & & & & & & & & & \\
\hline Canada Health Transfer & 8,706 & 9,584 & 860 & 890 & 816 & 832 & 1,817 & 1,923 & 3,172 & 3,248 \\
\hline Canada Social Transfer & 4,103 & 4,218 & 383 & 394 & 322 & 332 & 1,141 & 1,190 & 1,391 & 1,438 \\
\hline Total & 12,809 & 13,802 & 1,243 & 1,287 & 1,138 & 1,164 & 2,958 & 3,113 & 4,563 & 4,686 \\
\hline $\begin{array}{l}\text { OPTION 1: Equalized } \\
\text { to National Average }\end{array}$ & & & & & & & & & & \\
\hline Collections From 5\% GST & & 10,190 & & 899 & & 808 & & 3,080 & & 3,519 \\
\hline Eliminate CHT and CST & & $-13,802$ & & $-1,284$ & & $-1,164$ & & $-3,113$ & & $-4,686$ \\
\hline New Social Transfer & & 3,791 & & 348 & & 375 & & 288 & & 1,273 \\
\hline National Average GST Equalization & & 0 & & 38 & & 0 & & 0 & & 0 \\
\hline Change From Status Quo & & 179 & & 1 & & 19 & & 255 & & 106 \\
\hline $\begin{array}{l}\text { OPTION 2: Fully Equalized } \\
\text { National Average } \\
\text { Equalization }\end{array}$ & & & & & & & & & & \\
\hline Collections From 5\% GST & & 10,190 & & 899 & & 808 & & 3,080 & & 3,519 \\
\hline Eliminate CHT and CST & & $-13,802$ & & $-1,284$ & & $-1,164$ & & $-3,113$ & & $-4,686$ \\
\hline New Social Transfer & & 3,621 & & 348 & & 375 & & 36 & & 1,170 \\
\hline National Average GST Equalization & & 0 & & 38 & & 0 & & 0 & & 0 \\
\hline Change From Status Quo & & 9 & & 1 & & 19 & & 3 & & 3 \\
\hline
\end{tabular}

\section{Discussion}

Both options ensure that no province receives less under the new arrangement than they do under current arrangements. While this has a certain ends-justify-the-means aspect, it would also be politically acceptable because it is simply not possible for any new arrangement to create substantial winners and losers among provinces. 
Further, under both options, Ottawa retains a federal-provincial transfer. This should satisfy those who believe that Ottawa should maintain some influence over certain programs. The arguments in favour of Ottawa providing funding for post secondary education outweigh the arguments for federal involvement in other programs like health care, welfare and child programs. This is because there are more obvious spillovers associated with post secondary education. ${ }^{30}$ In short, health care reforms in one province have little impact on the economic or social opportunities of those in other provinces. In contrast, post secondary education policies have a much larger impact on the quality of the labour force, and with post secondary education it is much easier to succumb to the free rider temptation - under-invest in education in the hopes that promising students will just go to another jurisdiction for their education and come back.

The key difference between the two options is the method of equalizing the transfer of GST to provinces. In both cases, the provincial GST is arguably equalized above what the current equalization program would provide - a national average standard equalization with dwindling associated equalization in which the overall program is subject to a capped growth rate equal to nominal GDP. It is arguable because if Ottawa did this in the current year, it would subject equalization, including the new GST portion, to the ceilings imposed by the GDP growth rate rule.

The key difference between the options is the presence of associated equalization. Option 1 is consistent with current government policy, which is removing associated equalization from the CST and the CHT. It is therefore this paper's preferred option. But there are some strong arguments as well for Option 2 and a more generous treatment of equalization.

The first is simply a mater of real politic. It may not be realistic to expect that provinces will accept a change of this magnitude where the current have provinces came out winners while existing have not provinces come out essentially even. As noted, allowing a 5\% GST transfer to be equalized by the existing equalization program would result in Ontario coming out ahead by $\$ 178$ million, and Alberta by $\$ 425$ million.

The second way of justifying this more generous treatment of equalization is to argue that any transfer of tax points to the provinces, in order to be fair, must be fully equalized. Option 2 entrenches full equalization in a new associated equalization amount similar to that created for the 1977 transfer of personal and corporate income tax points.

Those who see this as super or back door equalization can argue that, over time, this equalization can move to a national average - as has been done in Budget 2007 with the associated equalization in the existing Canada Social Transfer and will be done with the Canada Health Transfer. However, as a simple matter of real politic, to make the proposal palatable to provinces, it must simply not create massive winners and losers and by making all provinces winners' it must also not break the bank in Ottawa. And Option 2 is roughly half a billion cheaper than Option 1 - essentially because Ottawa gets to keep the gains that have provinces would have made under Option 1.

30 Jack Mintz and Michael Smart, Why Tax Point Transfers Will Strengthen Canada (Ottawa: Centre for Research and Information on Canada, September 2002), 37-38. 


\section{THE PROVINCIAL PERSPECTIVE}

With federal transfers growing at double digit rates prior to the recession, the motivation for Ottawa to consider a tax point transfer is rather obvious - it limits future ad hoc growth in federal transfers.

A real question is: Why would the provinces want this? In fact, a number of provinces are already supportive. Within Quebec, there is consensus among all political parties for a tax point transfer. ${ }^{31}$ Indeed, the Quebec Commission on Fiscal Imbalance recommended precisely the swap proposed in this paper and received strong support within the province.

Alberta, too, has pushed for the idea of replacing federal transfers with tax point transfers and while an Alberta sales tax may cause some heartache for provincial politicians, the reality is that this transfer will mean no change for Alberta consumers who already pay the GST. ${ }^{32}$

Ontario, while it has not explicitly called for such a tax point transfer, has been moving steadily in that direction. It is a very small step from rejecting associated equalization and calling for all transfers outside of equalization to be equal per capita, to a call for a transfer of tax points. Manitoba is among other provinces that have explicitly endorsed a tax point transfer, albeit under its former government. ${ }^{33}$ Saskatchewan, which is quickly adjusting to life as have provinces, is likely to be supportive as well. So as a starting point, Alberta and Quebec - the wealthiest have and the wealthiest have not provinces, respectively, would be on side, with a reasonable prospect of bringing Ontario and Saskatchewan into the picture.

As for the other provinces, Figure 1 suggests a good part of the answer. Given the choice between any of the lines in that figure to fund social programs, any province - whether Newfoundland and Labrador or British Columbia - would be hard pressed to prefer transfers payments to a transfer of income tax or GST tax points.

Provinces may well argue that they have done well by relying on federal transfers in recent years - and they would be right. As noted already, federal transfers rose by double digit rates prior to the recession. But the real question for provinces is whether they are at the top of this cycle. With Ottawa's rhetoric about resolving the fiscal imbalance, it seems unlikely that budgets in the coming years will increase transfers at anything like the current rate. Further, fiscal pressures on Ottawa only serve to put downward, not upward, pressure on transfers. Provinces should, from a purely self-interested point of view, take this opportunity to lock in their gains. Indeed, if past experience is any guide, the provinces should be very nervous about how the federal government will approach reducing its deficit. As McKenzie and Kneebone show, in the last large federal retrenchment, almost a third was due to cutbacks in provincial transfers. ${ }^{34}$

31 The Commission on the Fiscal Imbalance was announced on March 22, 2001, by then Quebec premier Bernard Landry, the Commission was appointed in May, 2001, and the final report was delivered in March, 2000, and the Liberals have a long standing policy of support for a transfer of tax points. See Monique Jerome-Forget, A Question of Priorities, Equity and Accountability (Ottawa: Centre for Research and Information on Canada, September 2002), 29-32.

32 Report of the MLA Committee on Strengthening Alberta's Role in Confederation, Alberta International and Intergovernmental Relations, Government of Alberta, June 2004.

33 A Renewed Fiscal Partnership to Support Canada's Social Union, Budget Paper C, Government of Manitoba, 1999. The link is www.gov.mb.ca/finance/pdf/budget1999/fiscal.pdf .

34 Ron Kneebone and Ken McKenzie, Past (in)discretions: Canadian Federal and Provincial Fiscal Policy (Toronto: Centre for Public Management, University of Toronto Press, 1999). 
If federal transfers have indeed peaked, the GST may in fact be more generous over time than what is provided by recent budgets. The CST and CHT have been growing automatically by an annual average rate of 5.1\%. By comparison, revenues from the GST have grown at an average annual rate of $5.4 \%$ since its introduction.

Further, a transfer of GST revenues to the provinces would make it all but impossible for Ottawa to repeat the experience of transfers outlined in Figure 1. Indeed, had the provinces received only tax point transfers in 1977 instead of a combination of cash and tax points, they would have substantially higher, not to mention more consistent, revenues today. ${ }^{35}$

\section{THE TAXPAYER'S PERSPECTIVE}

A final, and perhaps most critical argument for provinces to receive more sources of revenue to meet their responsibilities is that it will enhance provincial accountability. ${ }^{36}$ Today, it is simply too easy for provinces to offload their responsibility for health care and other social programs on Ottawa - blaming them on the one hand for restraining their ability to act and on the other for failing to provide proper funding.

The transfer of GST revenues to provinces and the elimination of health transfers will transfer accountability for health care to provincial governments and their voters, who will have a much better connection between taxes paid and services received. As Mintz and Smart state, under the current system, "Ottawa raises the money, and the provinces spend it. The result of this fiscal churning is the 'co-dependent' constitutional relations we have today. No government has clear responsibility for delivering key programs and both sides blame the other when something goes wrong ... A tax point transfer would put an end to this fiscal illusion." ${ }^{37}$

Some critics will see these proposals as undermining the role of the federal government in health and other social policies, leading to a long-run decline in services throughout the nation. Under successive governments, Ottawa has long positioned itself to be the champion of panCanadian standards in health care - and cash transfers are the carrot and stick believed to keep the provinces in line. Perhaps it is high time to acknowledge that provincial voters are every bit as trustworthy as national voters in holding provincial governments accountable for the type of health and social programs that they want. ${ }^{38}$ National standards could be stifling needed reforms in the health-care system, and they have little economic rationale, since, as noted, health-care policies do not create spillover effects for other provinces.

35 Addressing the Fiscal Imbalance: Report of Provincial and Territorial Finance Ministers, prepared for discussion at the 2001 Annual Premiers Conference, Victoria, British Columbia, August 1-3, 2001. Chart on Page 9.

36 Ken McKenzie, Reflections on the Political Economy of Fiscal Federalism in Canada (Toronto: C.D. Howe Institute Working Paper) September 2005. Also see Jack Mintz and Michael Smart, Why Tax Point Transfers Will Strengthen Canada.

37 Jack Mintz and Michael Smart, Why Tax Point Transfers Will Strengthen Canada. See also Smart, C.D. Howe Working Paper: Federal Transfers: Principles, Practice, and Prospects, September 2005.

38 Herb Emery, Understanding the Political Economy of the Evolution and Future of Single-Payer Public Health Insurance in Canada (Calgary, School of Public Policy, February 2010). 
While these tax changes have no direct implications for the level of consolidated (federalprovincial) spending on health care, hardening government budget constraints and forcing politicians to confront fiscal and demographic realities is likely to lead to long-run, fundamental changes to the system. ${ }^{39}$ This is a good thing: the system needs such change. It is not enough to pour public money into the existing system. The increased demand for funds of the present system seems to be virtually unlimited. The only alternative is to limit growth of health care spending, and this will surely involve equality access rationing, catastrophe insurance, and price rationing in a sensible way. We must recognize that the fiscal flow supporting the current equilibrium is not unlimited. It hinges on expanded productivity, and dumping more and more money into health is not the way to expand productivity. It seems unavoidable that a greater proportion of public resources must be devoted to education and infrastructure in future, and less to health - or we run the risk of having less to spend on anything. Until people stop pretending that more public money is the solution, we will never be able to reach a solution, and we might do a lot of damage to the health of our economy in the process.

An important benefit of placing more of the explicit fiscal burden on the fiscally more challenged level of government - the provinces - is that it should make us face up to these fundamental problems sooner. Moreover, and on past evidence with good reason, we might expect that ten minds are better than one: that is, give the provinces a freer hand, and a stronger stimulus, to find solutions and some of them will indeed try different things. One of the conventional arguments for the superiority of the federal system is that provinces are laboratories in which we can work out different ways of dealing with public policy problems. One size does not fit all, but some ways of cutting the cloth might prove better than others. Saskatchewan led the way to our current health system in the 1950s. Perhaps it, or some other province, may lead the way to a sustainable health system for the 2010 s. We should let federalism do its job.

\section{CONCLUDING THOUGHTS}

This paper has made the case for transferring GST revenues from the federal government to the provinces, with the cost of doing so offset by reducing federal transfers for social programs. The strongest argument for doing so is that this will go much of the way to eliminating the fiscal imbalance by leading to greater alignment between provincial own-source revenues and provincial programs.

The paper argues that GST revenues should be the transferred to the provinces because it would push the final province to harmonize their sales tax with the GST, because the GST is a more stable revenue source for social programs, because the entire tax can be transferred and because the dollars that Ottawa would still transfer to the provinces could be used as leverage to ensure the federal government still maintains a consistent GST base across Canada.

Governments should have to raise enough revenues to pay for the expenditures they make. Turning GST revenues over to the provinces will bring our provinces much closer to this very basic and important imperative.

\footnotetext{
39 See McKenzie on the importance of this constraint in the context of fiscal federalism, Reflections on the Political Economy of Fiscal Federalism in Canada (Toronto: C.D. Howe Institute Working Paper), September 2005.
} 


\section{REFERENCES}

Baylor, Maximilian, and Louis Beausejour, Taxation and Economic Efficiency: Results from a Canadian CGE Model, Working paper, Department of Finance (2004).

Bird, Richard M., Taxation in Latin America: Reflections on Sustainability and the Balance between Efficiency and Equity, ITP Paper 0306, International Tax Program, (Rotman School of Management, University of Toronto, June, 2003).

Bird, Richard M., Taxing Sales Twice: International Experience with Multilevel Sales Taxes, in State Tax Notes (2005), 37 (11), 803-09.

Bird, Richard M. and Pierre-Pascal Gendron, CVAT, VIVAT, and Dual VAT, in International Tax and Public Finance, (2000), 7: 753-61.

Bird, Richard M. and Pierre-Pascal Gendron, VATs in Federal Countries: International Experience and Emerging Possibilities, in Bulletin for International Fiscal Documentation, (2001), 55(7,): 293-309.

Bird, Richard M. and Pierre-Pascal Gendron (forthcoming), Value-Added Taxation in Developing and Transitional Countries, (Cambridge University Press).

Bird, Richard M. and Kenneth J. McKenzie, Taxing Business: A Provincial Affair? (Toronto: C.D. Howe Institute, 2001).

Bird, Richard M. and Eric Zolt, Redistribution via Taxation: The Limited Role of the Personal Income Tax in Developing Countries, in UCLA Law Review, (2005), 52 (6): 1627-95.

Browning, Edgar K., Inequality and Poverty, in Southern Economic Journal (1989), 55: 819-30.

Chen, Duanje and Jack Mintz, Assessing Ontario's Fiscal Competitiveness, a paper prepared for the Institute for Competitiveness and Prosperity (2003).

Dalhby, Bev, Dealing with the Fiscal Imbalances: Vertical, Horizontal, and Structural, Working paper, C.D. Howe Institute (2005).

Ebrill, Liam et al., The Modern VAT (Washington: International Monetary Fund, 2000).

Keen, Michael and Stephen Smith, Viva VIVAT! in International Tax and Public Finance (2000), 7 (6): $741-51$.

McLure, Charles E., Implementing Subnational VATs on Internal Trade: The Compensating VAT (CVAT), International Tax and Public Finance, (2000), 7 (6): 723-40.

Mintz, Jack and Michael Smart, Income shifting, investment, and tax competition: Theory and evidence from provincial taxation in Canada, in Journal of Public Economics 88(6), (June 2004), 1149-1168.

Ontario Chamber of Commerce, Fairness in Confederation: A roadmap to recovery, unpublished working paper (2005).

Robinson, A.J., The Retail Sales Tax in Canada (Toronto: Canadian Tax Foundation, 1986).

Sharpe, Andrew, Linkages Between Economic Growth and Inequality: Introduction and Overview, in Canadian Public Policy 29 (Supplement, 2003).

Smart, Michael, Federal Transfers: Principles, Practice, and Prospects, C.D. Howe Working Paper, (September, 2005).

Winer, Stanley L., Some Evidence on the Effect of the Separation of Spending and Taxing Decisions, in Journal of Political Economy, (1983), 91: 126-40. 


\section{About the Author}

Ken Boessenkool is an Executive Fellow at The School of Public Policy at the University of Calgary and provides Senior Counsel through the communications firm GCl Canada. Ken has been a senior policy advisor to three national leaders and two Alberta Finance Ministers. He has been a policy chair for three winning national leadership campaigns and one provincial leadership campaign and has played senior strategic and policy roles in two national election campaigns. Ken has played formal advisory roles for Preston Manning (federal), Stockwell Day (provincial), Stephen Harper (federal) and Jim Dinning (provincial). Ken has written for the C.D. Howe Institute, the Atlantic Institute for Market Studies, the Institute for Research on Public Policy, the Montreal Economic Institute, the Fraser Institute, the Canada West Foundation, the Institute for Intergovernmental Relations (Queens), The School for the Study of State and Markets (Toronto), the Institute for Public Economics (Alberta) and The School of Public Policy (Calgary). Ken is a volunteer bard member on The CanadaIsrael Committee; The Cantos Music Foundation; The Canadian Friends of Hebrew University and the Forum of Federations. Ken has been a senior regulatory economist with two large national electricity firms as well as an independent economic consultant. Ken has an undergraduate degree from the University of Lethbridge and a graduate degree in economics from the University of Toronto. Ken and his wife Tammy have four daughters - including two teenagers - and lives in Chestermere, Alberta.

Ken writes frequent opinion editorials and has over 40 publications including the following:

- Does Alberta have a spending Problem (School of Public Policy, University of Calgary, February 2010)

- Federal and Provincial Programs for Early Childhood Development: A Schematic (Canada West Foundation, November 2008)

- Equalization and the Fiscal Imbalance: Options for Moving Forward (Canada West Foundation, February 2007)

- Taxing Incentives: How the Equalization program Distorts Tax Policy in Recipient Provinces (Atlantic Institute for Market Studies, June 2002)

- Ten Reasons to Remove Nonrenewable Resources from Equalization (in P. Boothe (ed.) Equalization: Helping Hand or Welfare Trap, Atlantic Institute for Market Studies, April 2002)

- Keeping Alberta on the Path of Fiscal Happiness (C.D. Howe Institute, October 2001)

- Give Mom and Dad a Break: Family Friendly Tax Options for Canada (Institute for Research on Public Policy, October 2001)

- Taking off the Shackles: Equalization and Natural Resource Development in Atlantic Canada (Atlantic Institute for Market Studies, May 2001)

- Putting Tax Policy in its Place: How Social Policy Took Over the Tax Treatment of the Family (in J. Richards and D. Allen (eds.) It Takes Two: The Family in Law and Finance, C.D. Howe Institute, 1999)

- Giving Mom and Dad a Break: Returning Fairness to Families in Canada's Tax and Transfer System (C.D. Howe Institute, November 1998) with J. Davies

- Clearly Canadian: Improving Equity and Accountability with an Overarching Equalization Program (C.D. Howe Institute, October 1998)

- Ending the Training Tangle: The Case against Federal-Provincial Programs under El (C.D. Howe Institute, February 1997) with W. Robson

- The Illusion of Equality: Provincial Distribution of the Canada Health and Social Transfer (C.D. Howe Institute, June 1996) 


\section{ABOUT THIS PUBLICATION}

The School of Public Policy Research Papers provide in-depth, evidence-based assessments and recommendations on a range of public policy issues. Research Papers are put through a stringent peer review process prior to being made available to academics, policy makers, the media and the public at large. Views expressed in The School of Public Policy Research Papers are the opinions of the author(s) and do not necessarily represent the view of The School of Public Policy.

\section{OUR MANDATE}

The University of Calgary is home to scholars in 16 faculties (offering more than 80 academic programs) and 36 Research Institutes and Centres including The School of Public Policy. Under the direction of Jack Mintz, Palmer Chair in Public Policy, and supported by more than 100 academics and researchers, the work of The School of Public Policy and its students contributes to a more meaningful and informed public debate on fiscal, social, energy, environmental and international issues to improve Canada's and Alberta's economic and social performance.

The School of Public Policy achieves its objectives through fostering ongoing partnerships with federal, provincial, state and municipal governments, industry associations, NGOs, and leading academic institutions internationally. Foreign Investment Advisory Committee of the World Bank, International Monetary Fund, Finance Canada, Department of Foreign Affairs and International Trade Canada, and Government of Alberta, are just some of the partners already engaged with the School's activities.

For those in government, The School of Public Policy helps to build capacity and assists in the training of public servants through degree and non-degree programs that are critical for an effective public service in Canada. For those outside of the public sector, its programs enhance the effectiveness of public policy, providing a better understanding of the objectives and limitations faced by governments in the application of legislation.

\section{DISTRIBUTION}

Our publications are available online at www.policyschool.ca.

\section{DISCLAIMER}

The opinions expressed in these publications are the authors' alone and therefore do not necessarily reflect the opinions of the supporters, staff, or boards of The School of Public Policy.

\section{COPYRIGHT}

Copyright (C) 2010 by The School of Public Policy.

All rights reserved. No part of this publication may be reproduced in any manner whatsoever without written permission except in the case of brief passages quoted in critical articles and reviews.

\section{ISSN}

1919-112x SPP Research Papers (Print)

1919-1138 SPP Research Papers (Online)

\section{DATE OF ISSUE}

December 2010

\section{MEDIA INQUIRIES AND INFORMATION}

For media inquiries, please contact Morten Paulsen at 403-453-0062.

Our web site, www.policyschool.ca, contains more information about The School's events, publications, and staff.

\section{DEVELOPMENT}

For information about contributing to The School of Public Policy, please contact Candice Naylen by telephone at 403-210-7099 or by e-mail at cnaylen@ucalgary.ca.

\section{EDITOR}

Claudia Cattaneo 


\section{PUBLICATIONS BY THE SCHOOL OF PUBLIC POLICY}

CANADA, THE G8, AND THE G20: A CANADIAN APPROACH TO SHAPING GLOBAL GOVERNANCE IN A SHIFTING INTERNATIONAL ENVIRONMENT

http:// policyschool.ucalgary.ca/files/publicpolicy/SMITH_finalfinal.pdf

Gordon S. Smith \& Peter C. Heap | November 2010

DIFFERENTIATING CANADA: THE FUTURE OF THE CANADA-US RELATIONSHIP http:// policyschool.ucalgary.ca/files/ publicpolicy/dobsonkuzmanovic\%20online.pdf Wendy Dobson \& Diana Kuzmanovic | November 2010

EXPANDING CANADA PENSION PLAN RETIREMENT BENEFITS: ASSESSING BIG CPP PROPOSALS http:/ / policyschool.ucalgary.ca/files/ public policy/Kesselman\%20CPP\%20online.pdf Jonathan R. Kesselman | October 2010

SECURITIES REGULATION IN CANADA AT A CROSSROADS

http://policyschool.ucalgary.ca/files/publicpolicy/Lortie\%20online.pdf

Pierre Lortie | October 2010

CANADA'S FOREIGN DIRECT INVESTMENT CHALLENGE: REDUCING BARRIERS AND ENSURING A LEVEL PLAYING FIELD IN FACE OF SOVEREIGN WEALTH FUNDS AND STATE-OWNED ENTERPRISES

http://policyschool.ucalgary.ca/files/publicpolicy/mattkrzepkowski\%20online2.pdf

Matt Krzepkowski \& Jack Mintz | October 2010

INCREASING THE AFFORDABILITY OF RENTAL HOUSING IN CANADA: AN ASSESSMENT OF ALTERNATIVE SUPPLY-SIDE MEASURES

http://policyschool.ucalgary.ca/files/publicpolicy/research_steeletomlinson_onlinefin2.pdf

Marion Steele \& Peter Tomlinson | September 2010

SHOULD GOVERNMENT FACILITATE VOLUNTARY PENSION PLANS?

http://policyschool.ucalgary.ca/files/publicpolicy/researchnielson.pdf

Norma L. Nielson | July 2010

CANADA'S TAX COMPETITIVENESS AFTER A DECADE OF REFORMS: STILL AN UNFINISHED PLAN http://policyschool.ucalgary.ca/files/publicpolicy/TaxCorp.pdf

Duanjie Chen \& Jack Mintz | May 2010

BRITISH COLUMBIA'S HARMONIZED SALES TAX: A GIANT LEAP IN THE PROVINCE'S COMPETITIVENESS http://www.policyschool.ucalgary.ca/files/publicpolicy/bctaxonline.pdf

Jack Mintz | March 2010

TAXING CANADA'S CASH COW: TAX AND ROYALTY BURDENS ON OIL AND GAS INVESTMENTS http://www.policyschool.ucalgary.ca/files/publicpolicy/cashcow1b.pdf

Jack Mintz \& Duanjie Chen| February 2010

DOES ALBERTA HAVE A SPENDING PROBLEM?

http://policyschool.ucalgary.ca/files/publicpolicy/albsp2.pdf

Ken Boessenkool | February 2010

REPLACING ALLOWANCES FOR CANADA'S NATIONAL POLITICAL PARTIES?

http://www.policyschool.ucalgary.ca/files/publicpolicy/Flanagan\%20\&amp;\%20Coletto\%200NLINE\%203.pdf

Tom Flanagan and David Coletto | January 2010 